\title{
PERLAKUAN PAJAK PERTAMBAHAN NILAI TRANSAKSI E-COMMERCE DI INDONESIA
}

\author{
Setiadi Alim Lim \\ Program Studi Akuntansi Politeknik Ubaya \\ Jalan Ngagel Jaya Selatan 169, Surabaya \\ Lilik Indrawati \\ Program Studi Manajemen \\ Fakultas Ekonomi Universitas Katolik Darma Cendika \\ Jalan Dr. Ir. H. Soekarno 201, Surabaya
}

\begin{abstract}
Developments in science and technology is very rapid at the end of the 20th century, especially information and communication technologies have caused changes in many areas of life, including the business life. One of the benefits of information and communication technologies in the business world is the support of the implementation of bisnis transactions are done online or so-called ecommerce (electronic commerce) through the use of the internet network. Ecommerce transactions are growing very rapidly from year to year. Given the potential tax revenue from this sector, governments around the world must give great attention to the taxation of e-commerce transactions, including the imposition of Value Added Tax. In Indonesia, the taxation of e-commerce transactions are regulated in Circular of the Director General of Tax No. SE-62/ PJ/2013 dated December 27, 2013. But what is regulated in Circular of the Director General of Tax No. SE-62/PJ/2013 dated December 27, 2013 is deemed still not enough to regulate all matters relating to the imposition of Value Added Tax on e-commerce transactions. Therefore, it is necessary to develop a set of rules comprehensive for the imposition of Value Added Tax on e-commerce transactions.
\end{abstract}

\begin{abstract}
ABSTRAK
Perkembangan ilmu pengetahuan dan teknologi yang sangat pesat pada akhir abad ke-20, khususnya teknologi informasi dan komunikasi telah menyebabkan perubahan pada berbagai bidang kehidupan, termasuk kehidupan bisnis. Salah satu manfaat dari teknologi informasi dan komunikasi pada dunia bisnis adalah dukungan terlaksananya transaksi binis yang dilakukan secara online atau biasa disebut e-commerce (electronic commerce) melalui pemanfaatan jaringan internet. Transaksi e-commerce ini berkembang sangat pesat dari tahun ke tahun. Mengingat besarnya potensi penerimaan pajak dari sektor ini, maka pemerintah di seluruh dunia harus memberikan perhatian yang besar terhadap pengenaan pajak atas transaksi e-commerce ini, termasuk pengenaan Pajak Pertambahan Nilai. Di
\end{abstract}


Indonesia pengenaan pajak terhadap transaksi $e$-commerce ini telah diatur dalam Surat Edaran Direktur Jenderal Nomor SE-62/PJ/2013 tanggal 27 Desember 2013. Namun apa yang diatur dalam Surat Edaran Direktur Jenderal Nomor SE62/PJ/2013 tanggal 27 Desember 2013 ini dirasa masih belum cukup untuk mengatur semua hal yang berhubungan dengan pengenaan Pajak Pertambahan Nilai untuk transaksi e-commerce. Oleh karena itu perlu disusun serangkaian peraturan yang lebih komprehensif untuk mengatur pengenaan Pajak Pertambahan Nilai untuk transaksi e-commerce.

Keywords: internet, online, offline, electronic commerce, digital product, business to business, business to consumer, cross border.

\section{PENDAHULUAN}

Memasuki akhir abad ke-20, ilmu pengetahuan dan teknologi mengalami kemajuan yang sangat pesat, khususnya kemajuan pada teknologi informasi dan komunikasi. Menurut Kazemi and Saeedy (2015) kemajuan dari teknologi informasi dan komunikasi dalam dua dekade terakhir dan perluasan aplikasinya pada berbagai bidang sosial dan ekonomi memunculkan suatu formasi bidang baru dari hubungan bersama antara individu, entitas, korporasi dan pemerintah. Konsep baru muncul di dalam literatur ekonomi dan perdagangan yang meninjau metode tradisional di dalam bisnis dan perdagangan di mana pekerjaan dan aktivitas ekonomi baru telah dibentuk.

Perkembangan teknologi informasi dan komunikasi yang ditandai dengan kemunculan jaringan internet menyebabkan perubahan pada berbagai bidang kehidupan. Keberadaan internet telah dimanfaatkan untuk berbagai hal, seperti untuk keperluan bisnis, hiburan, pendidikan, penelitian dan berbagai keperluan lainnya. Pengguna internet ini dari tahun ke tahun terus meningkat dengan cepat. Internet Telecommunication Union
(ITU) dalam World Trade Organization (2013) menyatakan bahwa jumlah pemakai internet pada tahun 2001 masih kurang lebih 500.000 orang dan pada tahun 2011 telah mencapai lebih dari 2 milyar orang. Sumber data dari ITU World Telecommunication dalam World Trade Organization (2013) menunjukkan jumlah pemakai internet yang tertinggi di Eropa dan yang terendah di Afrika. Di Eropa untuk setiap 100 orang ada $68,4 \%$ yang menggunakan internet. Di Amerika ada 53,4\%, di Commonwealth of Independent States ada 40,7\%, di negara-negara Arab ada 29,1\%, di Asia dan Pasifik ada 25,5\% dan di Afrika ada 12,4\%. Secara keseluruhan di seluruh dunia untuk setiap 100 orang ada 32,5\% yang menggunakan internet. Data dari Internet Live Stats. (2015) dalam Yapar et al. (2015) menunjukkan \% populasi penduduk dunia yang menggunakan internet: tahun 2009 sebesar 25,6\%, tahun 2010 sebesar 29,4\%, 2011 sebesar 32,5\%, 2012 sebesar 35,5\%, 2013 sebesar 37,9\% dan 2014 sebesar 40,4\%.

Salah satu kontribusi besar teknologi informasi dan komunikasi pada dunia bisnis adalah dukungan 
terlaksananya transaksi bisnis yang dilakukan secara online atau yang biasa dikenal sebagai e-commerce (electronic commerce). Dengan penyebaran yang cepat dari internet pada tahun 1990-an, suatu era baru dari transaksi perdagangan dimulai - era dari perdagangan elektronik (electronic commerce). E-commerce diartikan sebagai semua transaksi perdagangan, yang melibatkan individu swasta dan entitas perdagangan, yang berlangsung di atau melalui jaringan elektronik, yang telah merevolusi dunia bisnis modern (Pronina, 2011). World Trade Organization (2013) menyatakan e-commerce adalah penjualan atau pembelian barang dan jasa yang dilakukan melalui jaringan komputer dengan metode-metode yang secara khusus didesain untuk tujuan menerima atau menempatkan suatu pesanan.

E-commerce telah membuat transaksi penjualan dan pembelian menjadi lebih mudah dan tidak dibatasi oleh ruang dan waktu. Pada perdagangan model tradisional, seseorang yang ingin membeli barang harus mendatangi tempat penjual untuk melihat barang yang akan dibeli, menegosiasikan harganya, membelinya dan membawa barang tersebut. Hal ini seperti yang dikatakan Hanefah et al. (2008) bahwa pada perdagangan tradisional pelanggan dan pemasok berinteraksi secara tatap muka (face to face). Pada e-commerce, pembeli dapat melihat barang yang akan dibeli di website penjual atau penyelenggara perdagangan on line, menegosiasikan harga dan membelinya. Barang yang dibeli akan dikirimkan oleh penjual. Jadi pembeli mendapatkan kemudahan dan diuntungkan dengan tidak perlu mendatangi tempat penjual. Demikian pula penjual dapat menekan biaya karena tidak perlu menyediakan tempat atau toko untuk berjualan, sehingga dapat menjual barang dengan harga yang lebih murah.

Karena transaksi e-commerce sangat menguntungkan bagi pihak yang bertransaksi, maka diramalkan pelan tapi pasti model perdagangan tradisional akan semakin ditinggalkan dan transaksi perdagangan masa depan adalah menuju era $e$-commerce. Yapar et al. (2015) menyatakan saat ini $e$ commerce telah menjadi bagian penting dari kehidupan sehari-hari. Ecommerce menyediakan bisnis untuk menjual barang dan jasa dengan metode yang berbeda di seluruh dunia dan memungkinkan konsumen untuk mengakses barang dan jasa secara mudah. Menurut Borec et al. (2013) menyediakan barang dan jasa berbasis internet adalah bagian dari hampir kegiatan rutin sehari-hari dari setiap orang. Kecenderungan ini juga jelas dari semua statistik dan perkiraan yang memprediksi bagian dari perdagangan e-commerce akan meningkat secara signifikan di semua wilayah geografis di dunia untuk lima tahun berikutnya dan seterusnya. Sumber dari AT Kearney (2015) dalam Yapar et al. (2015) menunjukkan adanya kenaikan penjualan e-commerce dari tahun 2013 ke tahun 2014. Pada tahun 2013 jumlah penjualan e-commerce sebesar US\$ 694,8 billion dan di tahun 2014 sebesar US\$ 839,8 billion. Kemudian untuk tahun-tahun berikutnya diprediksi jumlah penjualan meningkat menjadi sebesar US\$ 994,5 billion untuk tahun 2015, 1.155,7 billion untuk tahun 2016, 1.328 billion untuk tahun 2017 dan 1.506 billion untuk tahun 2018.

Mengingat setiap tahun perdagangan melalui e-commerce ini selalu 
meningkat, maka pemerintah di semua negara di seluruh dunia perlu memberikan perhatian besar terhadap transaksi ini. Hal ini disebabkan perdagangan e-commerce ini dapat dengan mudah dilakukan, termasuk lintas negara (cross border) di mana kebanyakan pembeli dan penjual tidak melaporkan transaksi yang dilakukan dan tidak membayar kewajiban pungutan atas transaksi tersebut kepada pemerintah, sehingga potensi hilangnya pendapatan negara dari pungutan seperti bea masuk, pajak dan pungutan lainnya yang tidak dibayar menjadi sangat besar. Hellerstein (2002) menyatakan momok masif dari sejumlah kegiatan besar ekonomi dilakukan melalui perdagangan e-commerce oleh pengguna layanan provider jasa internet, di mana transaksinya tidak dapat dilacak dan lokasi transaksinya juga tidak dapat diidentifikasi dengan jelas, sehingga menimbulkan kekhawatiran otoritas fiskal di seluruh dunia. Menurut Hanefah et al. (2008) secara umum Vohra (2004), Horn (2003) and Cockfield (1999) percaya bahwa transaksi e-commerce tidak akan dapat dijawab dengan peraturan pajak yang sudah ada. Mereka menyatakan bahwa keberadaan peraturan pajak yang sudah dibuat pemerintah didesain untuk perdagangan konvensional di mana kehadiran secara fisik dapat dengan mudah diidentifikasi, oleh karenanya peraturan yang sama tidak dapat diaplikasikan pada transaksi $e$ commerce.

Dari uraian di atas nampak bahwa dengan kemajuan teknologi informasi dan komunikasi yang pesat membawa konsekuensi perubahan pada seluruh bidang kehidupan. Salah satunya adalah perubahan pada model transaksi bisnis. Kehadiran internet telah mendukung lahirnya bisnis $e$ commerce yang sudah menjadi gaya hidup sehari-hari dari masyarakat. Transaksi bisnis tradisional yang mengharuskan adanya tatap muka dari pelaku bisnis telah bergeser menjadi transaksi e-commerce yang tidak memerlukan tatap muka dari para pelaku bisnis. Omzet transaksi e-commerce dari tahun ke tahun terus meningkat dan diyakini pada masa depan transaksi bisnis akan didominasi dengan bentuk transaksi e-commerce.

Karena kegiatan bisnis e-commerce umumnya dilakukan oleh para pelaku bisnis yang identitas pelaku bisnis, transaksi dan lokasi transaksinya sulit untuk dilacak, maka pemerintah dari negara di seluruh dunia harus menyediakan instrumen yang memungkinkan berbagai transaksi tersebut dapat diketahui oleh otoritas pemerintah yang bertanggungjawab dan berbagai kewajiban pemungutan pemerintah atas transaksi yang dilakukan dapat dipungut dari para pelaku bisnis tersebut, termasuk pajak. Namun seperti yang dikatakan oleh Hanefah et al. (2008) menggunakan alat baru di rumah tua, peraturan pajak yang dibuat pada masa lalu untuk aplikasi transaksi bisnis bukan e-commerce akan sulit untuk diaplikasikan untuk mengatur pemajakan transaksi e-commerce.

Salah satu jenis pajak yang akan dikenakan pada transaksi bisnis adalah Pajak Pertambahan Nilai (Value Added Tax). Seperti halnya transaksi konvensional, transaksi ecommerce juga merupakan objek pemungutan Pajak Pertambahan Nilai. Setiap transaksi penyerahan Barang Kena Pajak dan atau Jasa Kena Pajak oleh pengusaha yang memiliki peredaran per-tahun melebihi Value Added 
Tax Threshold harus dipungut Pajak Pertambahan Nilai. Tulisan ini akan mengkaji apakah peraturan perpajakan di Indonesia, khususnya peraturan yang berhubungan dengan Pajak Pertambahan Nilai sudah mengatur tentang pengenaan Pajak Pertambahan Nilai terhadap transaksi e-commerce dan apakah peraturan tersebut sudah cukup memadai.

\section{TRANSAKSI E-COMMERCE}

E-commerce adalah perdagangan barang dan atau jasa yang dilakukan dengan menggunakan sarana dan peralatan elektronik (Yu, 2001; Hellerstein, 2002). LCG International AG (2013) menyatakan sarana elektronik yang digunakan adalah internet. $\mathrm{Yu}$ (2001) dan Basu (2001) mengartikan sarana dan peralatan elektronik yang dimaksud termasuk sesuatu seperti faksimil, teleks, electronic data interchange, internet, telpon. Sedangkan Canpolat (2001) dalam Yapar et al. (2015) menyatakan e-commerce umumnya dibuat menggunakan telpon, faksimil, internet, pembayaran elektronik, sistem pengiriman uang dan electronic data interchange. Tourban (2006) dalam Kazemi and Saeedy (2015) mengartikan e-commerce sebagai pembelian dan penjualan komoditas, jasa dan informasi melalui jaringan komputer termasuk internet.

Dari uraian di atas nampak banyak pengertian dan definisi yang diberikan untuk e-commerce. Seperti yang dikatakan oleh Krensel (2004) bahwa tidak ada standar definisi dari e-commerce, di mana definisi yang ada berbeda secara signifikan tergantung dari berbagai sumber dan penulis. Beberapa mendefinisikan meliputi semua transaksi keuangan dan komersial yang berlangsung secara elektro- nik, termasuk electronic data interchange, electronic fund transfer, dan semua aktivitas kartu kredit/debit. Sebagian yang lain membatasi $e$ commerce sebagai penjualan eceran kepada konsumen di mana transaksi dan pembayaran berlangsung pada suatu jaringan yang terbuka seperti internet.

Jadi seperti yang diungkapkan oleh Krensel (2004) belum ada standar baku mengenai pengertian e-commerce dan masing-masing penulis atau sumber tidak memberikan pengertian yang sama. Namun yang jelas hampir semuanya sepakat bahwa e-commerce mengacu pada suatu transaksi perdagangan yang menggunakan sarana dan peralatan elektronik. Walaupun banyak sarana dan peralatan elektronik yang dapat digunakan dalam transaksi e-commerce, namun untuk saat ini internet tetap merupakan sarana utama yang digunakan dalam transaksi $e$ commerce. Sedangkan sarana dan peralatan elektronik lainnya hanya bersifat mendukung atau membantu dalam transaksi bisnis.

Perkembangan transaksi $e$ commerce dari tahun ke tahun terus berkembang pesat, sejalan semakin berkembangnya jumlah pengguna internet. Hal ini disebabkan e-commerce memberikan banyak kemudahan melakukan transaksi bisnis, baik dari sudut penjual maupun dari sudut pembeli. World Trade Organization (2013) menyatakan pada tahun 1999 diestimasi ada 300 juta pengguna mengakses internet dan kurang lebih seperempat diantaranya melakukan pembelian secara online dari situs $e$ commerce dengan nilai sekitar US\$ 110 milyar. Tahun ini penjualan dari transaksi business to consumer global lebih dari US\$ 1,25 triliun. Menurut 
Azam (2012) $29^{\text {th }}$ Statistical Report on Internet Development in China memberikan data bahwa pada akhir Desember 2011 jumlah pengguna internet di China mencapai 513 juta pengguna, meningkat sebesar 56 juta pengguna dibandingkan tahun 2009. Sedangkan pihak yang belanja melalui online di China pada akhir Desember 2011 mencapai jumlah 194 juta, meningkat sebesar 33,44 juta atau 20,8\% dibandingkan dengan tahun 2010. Pada tahun-tahun berikutnya diperkirakan jumlah-jumlah ini akan semakin meningkat lagi.

\section{JENIS BISNIS E-COMMERCE}

Transaksi e-commerce jika ditinjau dari sudut pihak yang melakukan transaksi menurut OECD (2000) dalam Yapar et al. (2015) bisa dibedakan atas transaksi: Business to Business (B2B), Business to Consumer (B2C), Business to Government (B2G), Consumer to Business (C2B), Consumer to Consumer (C2C), Consumer to Government (C2G), Government to Government (G2G), Government to Business (G2B) dan Government to Consumer (G2C). Pandey and Agarwal (2014) menyatakan dari jenis transaksi e-commerce di atas, yang diterima secara umum oleh komunitas bisnis dan banyak digunakan adalah Business to Business (B2B), Business to Consumer (B2C) dan Consumer to Consumer (C2C). Business to Business (B2B) adalah transaksi jual beli melalui internet antara bisnis dan bisnis. Bagan alur transaksinya dapat dilihat pada Gambar 1. Business to Consumer (B2C) adalah transaksi jual beli melalui internet antara bisnis dan konsumen. Bagan alur transaksinya seperti terlihat pada Gambar 2. Consumer to Consumer (C2C) adalah transaksi jual beli melalui internet antara konsumen dengan konsumen. Bagan alur transaksinya seperti terlihat pada Gambar 3.

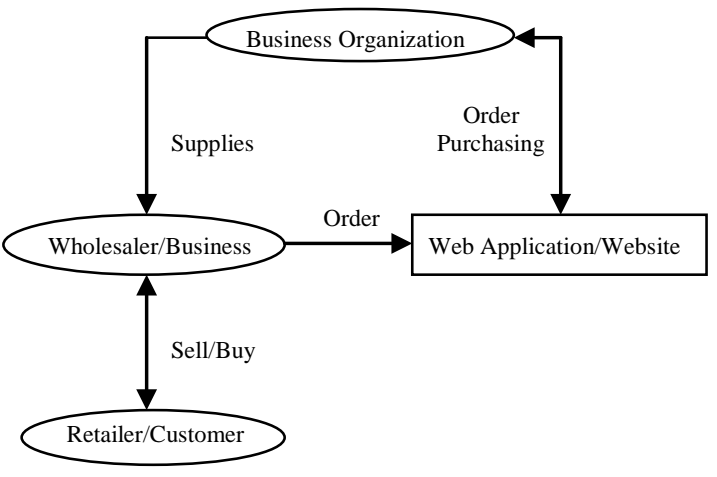

Gambar 1

Bagan Alur Transaksi B2B E-commerce Sumber: Pandey and Agarwal (2014)

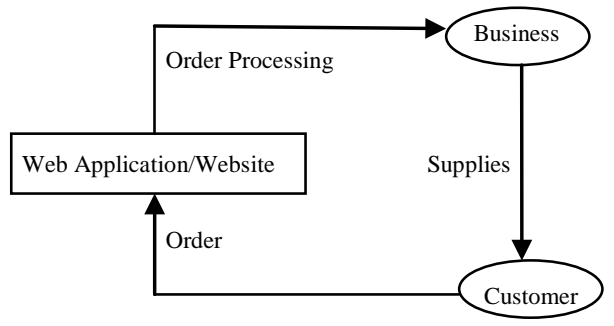

Gambar 2

Bagan Alur Transaksi B2C E-commerce Sumber: Pandey and Agarwal (2014)

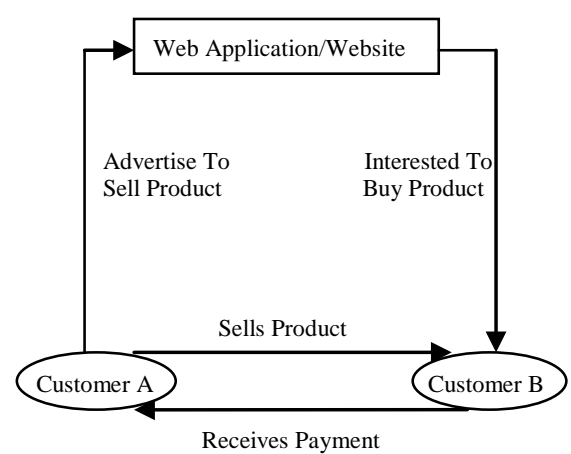

Gambar 3

Bagan Alur Transaksi C2C E-commerce Sumber: Pandey and Agarwal (2014) 
Jika dilihat dari proses penanganan transaksi secara keseluruhan e-commerce dapat dibedakan atas direct e-commerce dan indirect $e$ commerce (LCG International AG, 2013). Krensel (2004) menggunakan istilah transaksi bisnis offline yang tidak lain dari indirect e-commerce dan transaksi bisnis online yang tidak lain dari direct e-commerce.

Transaksi offline atau indirect e-commerce adalah transaksi e-commerce, di mana sebagian aktivitas transaksi diselesaikan menggunakan internet dan sebagian lagi tidak menggunakan internet. Misalkan kegiatan pemasaran termasuk pemasangan iklan dalam bentuk brosur, pemberian informasi spesifikasi barang atau jasa yang disediakan, penyediaan informasi penting lainnya, melakukan pemesanan barang dan jasa (bisa melalui registrasi menjadi anggota terlebih dahulu atau tidak) serta closing transaksi jual beli termasuk pembayaran dilakukan melalui internet, sedangkan aktivitas pengiriman barang atau pemberian jasa tidak dilakukan menggunakan internet. Jadi hanya sebagian aktivitas dari transaksi yang menggunakan media elektronik, sedangkan aktivitas lainnya tidak menggunakan media elektronik. Transaksi online atau direct e-commerce adalah transaksi e-commerce di mana seluruh aktivitas transaksi semuanya diselesaikan melalui internet. Jadi mulai aktivitas pra-penjualan seperti pemasangan iklan, pemberian informasi lainnya, pemesanan, pembayaran dan pengiriman barang dan jasa dilakukan melalui internet. Jadi seluruh aktivitas transaksi dari awal sampai dengan akhir dilakukan melalui media elektronik. Tidak semua transaksi e-commerce dapat dilakukan dengan direct e-commerce atau transaksi online ini. Direct e-commerce atau transaksi online ini hanya dapat dilakukan untuk barang atau jasa yang dapat dikirim secara elektronik. Krensel (2004) memberikan contoh barang yang dapat dikirim secara elektronik antara lain: mengunduh e-books, majalah, surat kabar, musik, perangkat lunak standar, perangkat lunak yang dipesan berdasarkan kebutuhan tertentu dan penggunaan jasa infomasi secara online.

Pengelompokkan jenis bisnis $e$ commerce secara permanen memang agak sulit, karena jumlah dan macam bisnis e-commerce ini terus bertumbuh dan bertambah dengan sangat cepat. Hal ini seperti yang dikatakan oleh Laudon and Traver (2004: 74) bahwa saat ini banyak model bisnis $e$ commerce dan akan lebih banyak lagi ditemukan setiap hari serta tidak ada satu cara yang benar untuk mengkategorikan model bisnis ini. Pendekatan dari Laudon and Traver (2004: 74) adalah mengkategorikan model bisnis ini menurut sektor e-commerce: B2C, B2B, C2C dan seterusnya, di mana model utama pada $\mathrm{B} 2 \mathrm{C} e$ commerce antara lain: portal, e-tailer, content provider, transaction broker, market creator, service provider, community provider dan model utama pada $\mathrm{B} 2 \mathrm{~B}$ e-commerce antara lain: $e$ distributor, e-procurement, exchange, industry consortium, private industrial network.

\section{PAJAK PERTAMBAHAN NILAI BISNIS E-COMMERCE}

Pajak Pertambahan Nilai merupakan pajak tidak langsung yang dipungut atas penyerahan barang dan jasa yang menjadi objek Pajak Pertambahan Nilai. Pajak Pertambahan Nilai merupakan jenis pajak tidak 
langsung yang paling populer dan dianut lebih dari 150 negara di seluruh dunia. Dalam melakukan pemungutan Pajak Pertambahan Nilai ada beberapa hal yang perlu diperhatikan, seperti apa saja yang menjadi objek pemungutan, apakah transaksi hanya merupakan transaksi lokal atau transaksi yang melibatkan negara lain, kapan waktu pemungutan, nilai pemungutan, siapa yang berwenang untuk melakukan pemungutan, tempat pemungutan serta bagaimana proses pengawasan dan penegakan hukum dilakukan. Untuk transaksi bisnis yang tradisional semua hal tersebut dapat dengan mudah diidentifikasi dan diverifikasi. Namun bila berhubungan dengan transaksi e-commerce informasi mengenai hal tersebut masih sulit untuk diperoleh dan diverifikasi.

Menurut Mahlunge (2014) ada beberapa isu yang perlu didiskusikan berkaitan dengan pemungutan Pajak Pertambahan Nilai untuk transaksi $e$ commerce, yaitu isu identitas dan lokasi, isu karakteristik, isu penegakan hukum serta isu international cross-border. Isu identitas dan lokasi berhubungan dengan adanya kemungkinan salah satu atau kedua belah pihak yang terlibat di dalam transaksi e-commerce menggunakan situs atau protokol internet yang tidak dapat ditelusuri sehingga mengakibatkan sulit mengidentifikasi dan memverifikasi identitas dan lokasi dari konsumen atau bisnis yang terlibat dalam transaksi $e$ commerce. Hal ini menyulitkan pemungutan Pajak Pertambahan Nilai atas transaksi e-commerce, karena identitas dan lokasi pihak yang bertransaksi tidak dapat diidentifikasi dan diverifikasi. Mengenai lokasi dari konsumen ini Krensel (2004) menyatakan ada beberapa pendekatan yang dapat diguna- kan untuk menetapkan lokasi konsumen, yaitu: juridiksi tempat tinggal atau tempat kedudukan yang diberitahu oleh konsumen kepada penjual; negara tempat kedudukan yang dibuktikan dari informasi kartu kredit; Nomor Pokok Wajib Pajak dari konsumen yang disampaikan kepada penjual; identifikasi data konsumen melalui penyedia jasa layanan internet (internet service provider). Isu karakteristik berkaitan dengan produk digital yang tidak dapat diklasifikasikan sebagai barang, karena penyerahannya diterima langsung oleh konsumen dari penjual dalam bentuk tidak berwujud dan bukan subjek yang dikontrol oleh aparat terkait. Hal ini menyebabkan kesulitan di dalam pemungutan Pajak Pertambahan Nilai atas transaksi $e$ commerce, disebabkan produk yang ditransaksikan tidak berwujud dan tidak dikontrol oleh aparat yang berwenang, khususnya produk tidak berwujud yang dibeli dari luar negeri yang tidak dapat dikontrol oleh aparat bea dan cukai. Isu penegakan hukum terkait dengan beberapa hal. Pertama, transaksi e-commerce produk digital menyulitkan untuk memastikan di mana dan kapan transaksi penyerahan berlangsung yang berarti sulit untuk menentukan kapan terjadi kewajiban pemungutan Pajak Pertambahan Nilai. Kedua, pada transaksi e-commerce sering sulit untuk menentukan identitas dan lokasi pihak-pihak yang terlibat dalam transaksi, sehingga proses penegakan hukum bagi pihak-pihak yang tidak patuh terhadap pemungutan dan pembayaran pajak juga sulit untuk dilaksanakan. Ketiga, transaksi e-commerce umumnya akan mengurangi panjangnya rantai distribusi dan banyak meniadakan bisnis perantara yang berakibat pada kesulitan pihak 
otoritas pajak dalam mengumpulkan dokumen dan bukti-bukti pendukung yang digunakan untuk proses penegakan hukum. Keempat, transaksi $e$ commerce akan membutuhkan biaya ekstra untuk melakukan penagihan dan pemeriksaan pajak dibandingkan dengan transaksi bisnis tradisional. Isu international cross-border berhubungan dengan transaksi e-commerce produk digital yang dijual oleh penjual dari luar negeri akan lebih sulit untuk dideteksi dan dikontrol oleh otoritas pajak pemenuhan kewajibannya untuk membayar Pajak Pertambahan Nilai. Sebagian besar transaksi e-commerce produk digital dari penjual luar negeri tidak membayar Pajak Pertambahan Nilai, sedangkan untuk penjual lokal hampir semuanya membayar Pajak Pertambahan Nilai. Akibatnya terjadi persaingan yang tidak sehat, karena harga jual produk digital yang dijual oleh penjual dari luar negeri akan lebih murah dibandingkan dengan yang dijual oleh penjual lokal, sebab harga jual penjual dari luar negeri tidak ditambah Pajak Pertambahan Nilai, sedangkan harga jual penjual lokal dibebani Pajak Pertambahan Nilai.

Krensel (2004) menyatakan berkaitan dengan pemungutan Pajak Pertambahan Nilai untuk transaksi $e$ commerce sistem pajak akan menghadapi 3 tantangan utama. Pertama, penjual dari negara dengan tarif Pajak Pertambahan Nilai yang rendah akan mendapatkan keuntungan harga karena menawarkan barang dengan harga yang lebih rendah dibandingkan dengan penjual dari negara yang menerapkan tarif Pajak Pertambahan Nilai tinggi. Kedua, tidak semua negara menerapkan sistem Pajak Pertambahan Nilai yang bisa mengarah pada pengenaan pajak tidak langsung berganda, karena untuk pajak tidak langsung belum ada usaha-usaha penghindaran pajak berganda. Ketiga, transaksi e-commerce telah mengubah tatanan rantai produksi dan distribusi. Kalau dalam model transaksi bisnis tradisional barang dan jasa yang dihasilkan produsen umumnya akan melalui sekian tahapan distribusi untuk sampai kepada konsumen akhir (melibatkan pedagang besar, pengecer dan pedagang perantara lainnya). Sedangkan pada transaksi bisnis e-commerce barang dan jasa yang dihasilkan oleh produsen dapat langsung sampai kepada konsumen akhir tanpa harus melalui pedagang perantara. Hal ini akan menimbulkan kesulitan bagi otoritas pajak dalam menentukan kewajaran harga jual dari produsen kepada konsumen karena tidak ada harga pembandingnya. Kalau sebelumnya otoritas pajak dapat membandingkan harga jual ke konsumen dengan harga jual pada tahapan sebelumnya yang ditentukan oleh pedagang besar, pengecer dan pedagang perantara lainnya.

Untuk tujuan pengenaan Pajak Pertambahan Nilai transaksi e-commerce, Bellheim et al. (2014) membedakan penyerahan dalam transaksi $e$ commerce menjadi 3, yaitu: (1) penyerahan produk digital yang dikirim melalui internet tanpa butuh kehadiran barang secara fisik, termasuk produk digital yang disimpan dalam satu pusat data dan didistribusikan dalam bentuk jasa penyediaan data; (2) penyerahan jasa lain melalui internet (contoh: konsultasi, pembelajaran); (3) penyerahan produk berwujud seperti barang yang dipesan dan dijual secara online.

Penyerahan produk digital sebagaimana dimaksud di atas termasuk membeli buku elektronik yang diunduh secara online atau membeli 
layanan jasa streaming online dengan membayar sejumlah fee tertentu. Produk digital ini diperoleh melalui akses internet secara otomatis yang umumnya melibatkan sedikit atau tanpa keterlibatan manusia. Penyedia produk atau jasa layanan digital ini dapat berada di lokasi yang sangat jauh dari lokasi konsumen, dan konsumen dapat mengaksesnya dari lokasi di mana saja yang tersedia layanan jaringan internet. Pembayaran untuk pembelian produk atau jasa layanan digital ini biasanya juga dilakukan melalui instrumen pembayaran digital (internet banking, mobile banking atau kartu kredit). Sedangkan penyerahan jasa lain melalui internet dan penyerahan produk berwujud seperti barang yang dipesan dan dijual secara online pada dasarnya mempunyai perspektif yang berbeda dengan penyerahan produk digital. Penyerahan jenis ini pemesanannya memang melalui online, tetapi pengiriman barang secara fisik dilakukan dengan cara biasa seperti melalui kurir. Transaksi bisnis e-commerce produk digital dikategorikan sebagai direct $e$ commerce, sedangkan transaksi $e$ commerce di luar produk digital tergolong sebagai transaksi indirect $e$ commerce.

Semua transaksi ini, baik yang direct e-commerce maupun indirect $e$ commerce, perlakuan Pajak Pertambahan Nilainya sama dengan transaksi bisnis konvensional. Jadi apabila pihak yang melakukan penyerahan Barang Kena Pajak dan atau Jasa Kena Pajak mempunyai total nilai penyerahan dalam 1 tahun melebihi batas Value Added Tax Threshold, maka pihak yang menyerahkan wajib memungut Pajak Pertambahan Nilai atas penyerahan tersebut. Namun berbeda dengan transaksi bisnis konvensional, pengenaan Pajak Pertambahan Nilai untuk bisnis e-commerce akan lebih sulit pengawasannya, lebih-lebih untuk transaksi produk digital. Jika transaksi bisnis konvensional kebanyakan dapat ditelusuri dari penyerahan fisik barang beserta dokumennya, sedangkan untuk transaksi e-commerce bukti penyerahan fisik ataupun dokumen pendukungnya biasanya sulit didapat dan ditelusuri.

Menurut Hellerstein (2002) untuk melihat implikasi transaksi $e$ commerce terhadap pajak konsumsi dari perspektif yang tepat, maka perlu membedakan transaksi e-commerce menjadi 4 kategori transaksi, yaitu: pertama, transaksi penjualan properti berwujud yang melibatkan bisnis dengan bisnis (B2B) yang dilakukan melalui sarana elektronik; kedua, transaksi penjualan produk digital yang melibatkan bisnis dengan bisnis (B2B); ketiga transaksi penjualan properti berwujud yang melibatkan bisnis dengan konsumen (B2C) yang dilakukan melalui sarana elektronik dan keempat, transaksi penjualan produk digital yang melibatkan bisnis dengan konsumen (B2C). Untuk transaksi penjualan properti berwujud, baik yang melibatkan bisnis dengan bisnis dan bisnis dengan konsumen perlakuan Pajak Pertambahan Nilainya sama dengan transaksi bisnis konvensional. Sedangkan untuk transaksi penjualan produk digital yang melibatkan bisnis dengan bisnis dan bisnis dengan konsumen akan menimbulkan banyak permasalahan, antara lain yang berhubungan dengan juridiksi dan karakteristik.

Jika transaksi bisnis e-commer$c e$ terjadi antara penjual dan pembeli yang berada di dalam satu negara, 
maka mekanisme pemungutan Pajak Pertambahan Nilai dilakukan secara normal oleh otoritas pajak di negara yang bersangkutan, tanpa melibatkan otoritas pajak dari negara lain. Sedangkan apabila transaksi bisnis yang terjadi melibatkan pihak penjual dan pembeli yang berada di negara berbeda, maka harus dilihat apakah transaksi tersebut melibatkan penjual dan pembeli yang keduanya berasal dari pihak bisnis (B2B) ataukah melibatkan penjual dari pihak bisnis dan pembeli dari pihak konsumen akhir (B2C). Bellheim et al. (2014) menyatakan transaksi e-commerce B2B yang melibatkan digital produk sesuai prinsip destinasi adalah subjek Pajak Pertambahan Nilai di lokasi di mana pembeli bisnis bertempat kedudukan. Tetapi dimungkinkan dengan peraturan khusus untuk mengaplikasikan pemungutan Pajak Pertambahan Nilai di lokasi penjual bisnis bertempat kedudukan. Sedangkan untuk transaksi B2C di bawah aturan Pajak Pertambahan Nilai negara-negara Uni Eropa, transaksi berhubungan dengan digital e-commerce dapat dipajaki di tempat di mana konsumen akhir bertempat kedudukan dari pada di tempat di mana supplier bertempat kedudukan.

Transaksi e-commerce yang melibatkan lebih dari satu negara termasuk transaksi perdagangan internasional. Transaksi ini bagi pihak penjual termasuk transaksi penjualan ekspor, sedangkan untuk pihak pembeli tergolong transaksi pembelian impor. Pengaturan yang umum berlaku untuk transaksi ekspor ini, negara di mana penjual bertempat kedudukan yang akan memungut Pajak Pertambahan Nilai dengan tarif $0 \%$, sedangkan negara di mana pembeli bertempat kedudukan akan memungut
Pajak Pertambahan Nilai dengan tarif pajak sesuai ketentuan yang berlaku. Menurut Bozdoğanoğlu (2015) transaksi dengan perusahaan asing dikenal sebagai proses Reverse-Charge dan Pajak Pertambahan Nilai direfleksikan kepada pelanggan. Aturan utama adalah Pajak Pertambahan Nilai menjadi milik dari negara di mana jasa tersebut dikonsumsi.

Pemenuhan kewajiban pemungutan Pajak Pertambahan Nilai untuk transaksi e-commerce yang melibatkan penjual dari pihak bisnis dan pembeli dari pihak konsumen akhir (B2C) akan lebih sulit untuk dideteksi dibandingkan dengan transaksi e-commerce yang melibatkan penjual dari pihak bisnis dengan pembeli dari pihak bisnis (B2B). Padahal dalam realita yang ada transaksi e-commerce yang melibatkan penjual dari pihak bisnis dengan pembeli dari pihak konsumen akhir (B2C) jumlahnya sangat besar baik dari jumlah transaksi maupun nilai transaksinya. Karena itu perlu ada suatu mekanisme pengawasan pemungutan Pajak Pertambahan Nilai yang lebih baik dibandingkan dengan transaksi konvensional pada umumnya. Dalam hal ini pengawasan terhadap dokumen bukti terjadinya transaksi merupakan hal penting untuk menelusuri apakah Pengusaha Kena Pajak sudah memungut dan membayar Pajak Pertambahan Nilai dari transaksi penyerahan Barang Kena Pajak dan atau Jasa Kena Pajak. Pada transaksi $e$ commerce dokumen bukti terjadinya transaksi ini yang sulit diperoleh.

Berkaitan dengan bukti transaksi e-commerce menurut Bellheim et al. (2014) beberapa contoh bukti informasi komersial yang dapat dijadikan dasar untuk melakukan pemungutan pajak atas terjadinya transaksi 
antara lain: alamat penagihan pelanggan, alamat IP (Internet Protocol Address) dari alat yang digunakan oleh pelanggan, detil bank seperti lokasi bank dari rekening pelanggan yang digunakan untuk pembayaran, negara dari SIM card yang digunakan oleh pelanggan, lokasi darat dari pelanggan yang mendapatkan layanan transaksi e-commerce dan informasi lainnya. Semua bukti yang berupa informasi ini tidak semuanya dalam bentuk fisik nyata (hard-copy) dan untuk mendapatkannya juga tidak mudah. Karena itu perlu adanya suatu peraturan khusus untuk transaksi e-commerce yang mengatur mengenai kapan Pajak Pertambahan Nilai terutang, dokumen apa yang digunakan sebagai bukti pemungutan pajak, bagaimana mekanisme pemungutan, penyetoran dan pelaporannya serta yang terpenting bagaimana mekanisme pengawasannya.

Bozdoğanoğlu (2015) menyatakan masalah yang terjadi dalam implementasi Pajak Pertambahan Nilai berkaitan dengan transaksi e-commerce sering berhubungan dengan kepribadian mereka yang menjadi pihak di dalam bertransaksi. Jadi apabila pihak yang terlibat dalam transaksi e-commerce umumnya mempunyai kepribadian cenderung tidak patuh terhadap kewajiban membayar pajak, maka secara otomatis pemungutan Pajak Pertambahan Nilai untuk transaksi $e$ commerce akan menghadapi banyak kendala.

Menurut Mahlunge (2014) OECD berdasarkan konferensi Ottawa pada tahun 1998 telah memberikan beberapa rekomendasi berkaitan dengan pengenaan pajak untuk transaksi e-commerce. Rekomendasi pertama adalah aturan mengenai pajak konsumsi untuk perdagangan lintas negara yang memberikan kewenangan pada juridiksi atau negara di mana konsumsi terjadi untuk melakukan pemungutan pajak konsumsi. Rekomendasi kedua dari OECD berupa kesepakatan yang menyatakan transaksi penyerahan produk digital tidak akan diperlakukan sebagai transaksi penyerahan barang. Rekomendasi ketiga atau terakhir menyatakan suatu metode reversecharge atau mekanisme penilaian sendiri (self assessment) akan digunakan untuk bisnis dan organisasi di dalam suatu negara yang memperoleh jasa atau properti tidak berwujud dari luar negeri. Ketiga rekomendasi ini oleh OECD kemudian dirinci lagi dalam beberapa pedoman. Pedoman pertama berkaitan dengan karakteristik produk digital dan tidak berwujud. OECD menyatakan penyerahan konten produk digital dan tidak berwujud bukan penyerahan barang. Pedoman kedua berhubungan dengan definisi tempat di mana konsumsi dilakukan. Tempat konsumsi untuk transaksi B2B adalah juridiksi atau negara di mana bisnis penerima/pembeli bertempat kedudukan. Sedangkan untuk transaksi B2C tempat konsumsi adalah juridiksi atau negara di mana penerima/pembeli bertempat tinggal. Bila penerima/pembeli mempunyai tempat tinggal yang lebih dari satu, maka juridiksi atau negara yang dipakai adalah negara atau juridiksi di mana penerima/pembeli majoritas bertempat tinggal. Pedoman ketiga berkaitan dengan mekanisme penagihan. Untuk transaksi lintas negara yang pemungutan pajaknya biasanya dilakukan oleh otoritas bea dan cukai tidak dapat diterapkan untuk transaksi e-commerce digital produk, karena tidak ada barang secara fisik yang masuk melalui prosedur kepabeaan. Oleh karena itu OECD mereko- 
mendasikan penggunaan metode reverse charge/self assessment dan meregistrasi penjual sebagai pemungut pajak. Krensel (2004) menyatakan ada 5 mekanisme yang dapat digunakan untuk melakukan pemungutan Pajak Pertambahan Nilai, yaitu: self assessment/reverse charge, registration of non residents, tax at source and transfer, collection by trusted third parties dan technology based solutions. Pedoman keempat berhubungan dengan administrasi perpajakan. Ada 2 hal yang diuraikan pada pedoman ini. Hal pertama berhubungan dengan penyederhanaan registrasi untuk penjual dari luar negeri yang prosesnya dapat dilakukan secara online ke website dari otoritas pajak. Hal kedua berhubungan dengan verifikasi status dan juridiksi dari pembeli. Dalam hal otoritas pajak menggunakan kedua metode, yaitu reverse charge dan registrasi, maka penjual dari luar negeri butuh untuk memverifikasi status dari pembeli untuk keperluan menggeser beban pajak (dalam kasus pembeli adalah bisnis) dan menagih serta menyetorkan pajak (dalam kasus pembeli adalah konsumen pribadi).

Rekomendasi dari OECD ini menjadikan acuan banyak negara untuk mengatur pemungutan Pajak Pertambahan Nilai atas transaksi e-commerce, khususnya untuk objek produk digital dan transaksi yang terjadi lintas negara. Afrika Selatan adalah salah satu negara yang melakukan perubahan dalam peraturan pajaknya untuk diselaraskan dengan rekomendasi dari OECD. Dalam peraturan pajak di Afrika Selatan didefinisikan pengertian e-commerce sebagai penyerahan jasa di tempat di mana pesanan atau pengiriman jasa layanan tersebut dilakukan secara elektronik. Peraturan yang ada juga mencantumkan daftar jasa elektronik yang akan menjadi objek Pajak Pertambahan Nilai. Ditetapkan pula batasan jumlah penyerahan jasa elektronik selama 12 bulan yang mengharuskan pihak yang menyerahkan untuk menjadi Pengusaha Kena Pajak (VAT Threshold), termasuk pihak yang tidak bertempat kedudukan atau bertempat tinggal di Afrika Selatan. Pengusaha luar negeri yang menyerahkan jasa elektronik ke Afrika Selatan melebihi VAT Threshold harus menjadi Pengusaha Kena Pajak luar negeri. Proses untuk menjadi Pengusaha Kena Pajak luar negeri dilakukan melalui registrasi secara online dan prosesnya akan diselesaikan dalam waktu 72 jam. Penyetoran dan pelaporan Surat Pemberitahuan (SPT) untuk Pengusaha Kena Pajak luar negeri dilakukan secara elektronik.

Transaksi e-commerce juga berkembang dengan sangat pesat di negara-negara Uni Eropa. Untuk merespon perkembangan tersebut Uni Eropa kemudian melakukan amandemen The Sixth Directive yang mengatur tentang pemungutan Pajak Pertambahan Nilai di negara-negara Uni Eropa. Dalam amandemen tersebut dijelaskan bahwa produk digital adalah jasa yang disediakan secara elektronik (electronically supplied services (e.s.s)) selanjutnya disebut jasa elektronik saja. Juga telah dibuat daftar jasa yang dimasukkan sebagai jasa elektronik. Peraturan yang ada menyatakan penjualan jasa elektronik oleh penjual yang berada di negara Uni Eropa kepada pembeli konsumen akhir yang berada di luar negara Uni Eropa, atau kepada pembeli bisnis yang berada di negara Uni Eropa dianggap sebagai penjualan jasa elektronik di lokasi pembeli, di mana loka- 
si tersebut adalah lokasi konsumen bertempat kedudukan atau bertempat tinggal, yang berupa alamat tetap atau alamat di mana biasanya dia berada. Ini berarti penjualan e-commerce dari penjual di negara Uni Eropa kepada pembeli yang berada di luar negara Uni Eropa dikecualikan dari pengenaan Pajak Pertambahan Nilai.

Sedangkan untuk transaksi penjualan e-commerce yang dilakukan oleh penjual dari luar negara Uni Eropa kepada pembeli yang berada di negara Uni Eropa, pemungutan Pajak Pertambahan Nilainya dilakukan dengan menggunakan mekanisme reverse charge untuk pemungutan Pajak Pertambahan Nilai transaksi B2B ecommerce dan metode registrasi penjual yang berasal dari luar wilayah Uni Eropa untuk pemungutan Pajak Pertambahan Nilai transaksi B2C ecommerce. Uni Eropa tidak menentukan jumlah minimum penjualan dalam periode 12 bulan untuk kewajiban registrasi bagi penjual yang berasal di luar wilayah Uni Eropa (VAT Threshold). Jadi semua penjual dari luar wilayah Uni Eropa yang melakukan transaksi B2C e-commerce wajib untuk melakukan registrasi. Untuk mempermudah proses registrasi dilakukan penyederhanaan proses registrasi dengan menerapkan skema registrasi khusus secara online yang diberi nama One-Stop-Shop (OSS) Scheme yang terhitung mulai 1 Januari 2015 digantikan dengan Mini One Stop Shop (MOSS) Scheme.

\section{PAJAK PERTAMBAHAN NILAI TRANSAKSI E-COMMERCE DI INDONESIA}

Di Indonesia pengenaan Pajak Pertambahan Nilai untuk transanksi $e$ commerce diatur dalam Surat Edaran
Direktur Jenderal Pajak Nomor SE-62/ PJ/2013 tanggal 27 Desember 2013 tentang Penegasan Ketentuan Perpajakan atas Transaksi e-commerce. Ada beberapa hal yang diatur dalam Surat Edaran Direktur Jenderal Pajak ini berkaitan dengan perlakuan Pajak Penghasilan dan Pajak Pertambahan Nilai untuk transaksi e-commerce. Di sini yang akan diuraikan hanya yang berhubungan dengan perlakuan Pajak Pertambahan Nilai.

Dalam Surat Edaran Direktur Jenderal Pajak ini disebutkan bahwa tidak ada perbedaan perlakuan perpajakan antara transaksi e-commerce dan transaksi perdagangan barang dan/atau jasa lainnya. Semua ketentuan dalam Undang-Undang Pajak Pertambahan Nilai dan peraturan pelaksanaannya juga berlaku bagi Wajib Pajak yang melakukan transaksi e-commerce. Pada Surat Edaran Direktur Jenderal Pajak ini model transaksi e-commerce dikelompokkan menjadi 4 model transaksi e-commerce, yaitu: Online Marketplace, Classified Ads, Daily Deals, Online Retail.

Model transaksi Online Marketplace adalah kegiatan menyediakan tempat kegiatan usaha berupa toko internet di mal internet sebagai tempat Online Marketplace Merchant menjual barang dan/atau jasa. Dalam model transaksi e-commerce ini ada 3 pihak yang terlibat dalam kegiatan bisnis, yaitu: penyelenggara Online Market place, Online Marketplace Merchant (Penjual) dan pembeli serta biasanya terdiri dari 3 tahapan.

Tahap pertama, penyelenggara Online Marketplace akan menjual jasa penyediaan tempat dan/atau waktu dalam media lain untuk penyampaian informasi kepada Online Marketplace Merchant yang merupakan Jasa Kena 
Pajak (JKP). Atas penyerahan jasa ini penyelenggara Online Marketplace akan memperoleh imbalan berbentuk monthly fixed rate, rent fee, registration fee, fixed fee atau subscription fee. Penyelenggara Online Marketplace akan memungut Pajak Pertambahan Nilai atas penyerahan jasa ini kepada Online Marketplace Merchant. Apabila penyerahan Jasa Kena Pajak di dalam daerah pabean, maka Pajak Pertambahan Nilai akan dipungut dan disetorkan oleh penyelenggara Online Marketplace. Namun jika penyelenggara Online Marketplace berada di luar daerah pabean, maka Pajak Pertambahan Nilai akan disetorkan oleh Online Marketplace Merchant.

Tahap kedua, saat Online Marketplace Merchant menjual Barang Kena Pajak dan atau Jasa Kena Pajak kepada pembeli. Apabila penyerahan dilakukan di dalam daerah pabean, maka Online Marketplace Merchant akan memungut Pajak Pertambahan Nilai dengan tarif $10 \%$. Namun apabila penyerahan berupa ekspor Barang Kena Pajak berwujud, ekspor Barang Kena Pajak tidak berwujud dan atau ekspor Jasa Kena Pajak, maka Online Marketplace Merchant akan memungut Pajak Pertambahan Nilai dengan tarif 0\%. Pajak Pertambahan Nilai dipungut pada saat pembayaran diterima oleh penyelenggara Online Marketplace dari pembeli.

Tahap ketiga, saat penyerahan hasil penjualan dari penyelenggara Online Marketplace kepada Online Marketplace Merchant. Pada saat menyerahkan hasil penjualan kepada Online Marketplace Merchant, penyelenggara Online Marketplace akan memotongkan sejumlah nilai atas jasa penjualan yang bisa berbentuk per sale fee, biaya service provider settlement, fee penggunaan kartu kredit/kartu debit, internet banking dan lain-lain dari jumlah nilai penjualan yang diserahkan. Atas jasa yang dipungut ini penyelenggara Online Marketplace harus memungut Pajak Pertambahan Nilai dari Online Marketplace Merchant.

Model transaksi Classified Ads adalah kegiatan menyediakan tempat dan atau waktu untuk memajang konten (teks, grafik, video penjelasan, informasi dan lain-lain) barang dan atau jasa bagi pengiklan untuk memasang iklan yang ditujukan kepada pengguna iklan melalui situs yang disediakan oleh penyelenggara Classified Ads. Ada 3 pihak yang terlibat dalam model transaksi ini, yaitu: penyelenggara Classified Ads, pengiklan dan pengguna iklan. Pada model transaksi ini penyelenggara Classified Ads akan melakukan penyerahan Jasa Kena Pajak (JKP) kepada pengiklan. Oleh karena itu penyelenggara Classified Ads akan memungut Pajak Pertambahan Nilai dari pengiklan sebagai pihak yang menerima penyerahan jasa. Apabila penyerahan dilakukan di dalam daerah pabean, maka Pajak Pertambahan Nilai akan dipungut dan disetorkan oleh penyelenggara Classified Ads. Sedangkan bila yang menyerahkan jasa adalah pihak yang berada di luar daerah pabean, maka penyetoran Pajak Pertambahan Nilai akan dilakukan oleh pengiklan sebagai pihak pengguna jasa.

Model transaksi Daily Deals adalah kegiatan menyediakan tempat kegiatan usaha berupa situs Daily Deals sebagai tempat Daily Deals Merchant menjual barang dan atau jasa kepada pembeli dengan menggunakan voucher sebagai sarana pembayaran. Ada 3 pihak yang terlibat dalam model transaksi ini, yaitu: penyeleng- 
gara Daily Deals, Daily Deals Merchant dan pembeli. Pada model transaksi ini ada 3 tahap proses bisnis.

Proses bisnis tahap pertama adalah saat penyelenggara Daily Deals menyediakan tempat dan waktu berupa situs yang dapat digunakan Daily Deals Merchant untuk menjual barang dan atau jasa kepada pembeli. Atas penyerahan jasa ini penyelenggara Daily Deals akan memperoleh imbalan berbentuk monthly fixed rate, rent fee, registration fee, fixed fee atau subscription fee. Penyelenggara Daily Deals akan memungut Pajak Pertambahan Nilai atas penyerahan jasa ini kepada Daily Deals Merchant. Apabila penyerahan Jasa Kena Pajak di dalam daerah pabean, maka Pajak Pertambahan Nilai akan dipungut dan disetorkan oleh penyelenggara Daily Deals. Namun jika penyelenggara Daily Deals berada di luar daerah pabean, maka Pajak Pertambahan Nilai akan disetorkan oleh Daily Deals Merchant.

Proses bisnis tahap kedua adalah saat Daily Deals Merchant menjual Barang Kena Pajak dan atau Jasa Kena Pajak kepada pembeli. Apabila penyerahan dilakukan di dalam daerah pabean, maka Daily Deals Merchant akan memungut Pajak Pertambahan Nilai dengan tarif $10 \%$. Namun apabila penyerahan berupa ekspor Barang Kena Pajak berwujud, ekspor Barang Kena Pajak tidak berwujud dan atau ekspor Jasa Kena Pajak, maka Daily Deals Merchant akan memungut Pajak Pertambahan Nilai dengan tarif 0\%. Pajak Pertambahan Nilai dipungut pada saat pembayaran diterima oleh penyelenggara Daily Deals dari pembeli atas penjualan voucher untuk perolehan Barang Kena Pajak dan atau Jasa Kena Pajak.
Proses bisnis tahap ketiga adalah saat penyerahan hasil penjualan dari penyelenggara Daily Deals kepada Daily Deals Merchant. Pada saat menyerahkan hasil penjualan kepada Daily Deals Merchant, penyelenggara Daily Deals akan memotongkan sejumlah nilai atas jasa penjualan yang bisa berbentuk per sale fee, biaya service provider settlement, fee penggunaan kartu kredit/kartu debit, internet banking dan lain-lain dari jumlah nilai penjualan yang diserahkan. Atas jasa yang dipungut ini penyelenggara Daily Deals harus memungut Pajak Pertambahan Nilai dari Daily Deals Merchant. Jadi model transaksi Daily Deals hampir sama dengan model transaksi Online Marketplace. Perbedaannya hanya berhubungan dengan cara pembayarannya saja. Jika pada model transaksi Online Marketplace pembayaran atas barang yang dibeli dengan menggunakan uang yang dibayarkan kepada penyelenggara Online Marketplace melalui berbagai media pembayaran seperti transfer, kartu kredit dan cara pembayaran lainnya. Sedangkan pada model transaksi Daily Deals pembayaran atas barang yang dibeli dengan menggunakan voucher. Untuk tahapan proses bisnis dari kedua model transaksi ini juga sama-sama meliputi 3 tahapan proses bisnis. Pengenaan Pajak Pertambahan Nilai pada setiap tahapan proses bisnis dari kedua model transaksi ini juga sama.

Model transaksi Online Retail adalah kegiatan menjual barang dan atau jasa yang dilakukan oleh penyelenggara Online Retail kepada pembeli di situs Online Retail. Pihak yang terlibat dalam transaksi e-commerce ini adalah: penyelenggara Online Retail yang juga sekaligus merupakan 
Online Retail Merchant dan pembeli. Transaksi ini seperti transaksi jual beli biasa yang hanya melibatkan 2 pihak yaitu penjual dan pembeli, namun transaksinya dilakukan melalui bantuan internet. Dalam hal ini setiap terjadi transaksi jual beli, maka pihak penjual dalam hal ini penyelenggara Online Retail yang juga sekaligus merupakan Online Retail Merchant akan memungut Pajak Pertambahan Nilai dari pihak pembeli.

\section{EVALUASI PENGENAAN PAJAK PERTAMBAHAN NILAI UNTUK TRANSAKSI E-COMMERCE DI INDONESIA}

Undang-Undang Nomor 8 Tahun 1983 tentang Pajak Pertambahan Nilai sebagaimana telah diubah beberapa kali terakhir dengan UndangUndang Nomor 42 Tahun 2009 tidak mengatur secara khusus mengenai pengenaan Pajak Pertambahan Nilai untuk transanksi e-commerce. Pengaturan hanya dilakukan dalam Surat Edaran Direktur Jenderal Pajak Nomor SE-62/ PJ/2013 tanggal 27 Desember 2013 tentang Penegasan Ketentuan Perpajakan atas Transaksi e-commerce. Dalam Surat Edaran Direktur Jenderal Pajak ini dijelaskan bahwa perlakuan Pajak Pertambahan Nilai untuk transaksi e-commerce sama dengan transaksi perdagangan biasa yang perlakuan perpajakannya menga$\mathrm{Cu}$ pada ketentuan perpajakan yang sudah ada. Secara lebih rinci lagi pada lampirannya, Surat Edaran Direktur Jenderal Pajak ini hanya mengatur pada hal yang lebih bersifat operasional pada 4 jenis model transaksi $e$ commerce.

Bila dibandingkan dengan apa yang telah diatur oleh negara-negara lain, pengaturan yang dilakukan dalam peraturan perpajakan di Indonesia berkaitan dengan pengenaan Pajak Pertambahan Nilai untuk transaksi $e$ commerce masih belum cukup. Hal-hal yang bersifat konseptual, mendasar dan operasional berkaitan dengan pengenaan Pajak Pertambahan Nilai atas transaksi $e$-commerce perlu diatur secara khusus seperti: apa definisi atau batasan dari transaksi e-commerce, karakteristik barang dan atau jasa yang menjadi objek transaksi e-commerce, identitas dan lokasi masing-masing pihak yang terlibat dalam transaksi $e$ commerce, pengaturan berkaitan dengan transaksi e-commerce lintas negara (cross-border), mekanisme pemungutan, penyetoran, pelaporan, pengawasan dan penegakan hukum serta halhal penting lainnya.

Pengaturan secara khusus ini perlu dilakukan mengingat transaksi $e$ commerce ini dari tahun ke tahun terus meningkat baik dari jumlah transaksi maupun nilai transaksi. Sedangkan pemasukan pemungutan Pajak Pertambahan Nilai dari transaksi ini walaupun belum ada penelitian yang valid diperkirakan masih sangat minim dan sangat tidak sesuai dengan besarnya nilai transaksi e-commerce yang terjadi. Masih banyak Wajib Pajak yang kemungkinan melakukan penghindaran pembayaran pajak, baik Pajak Penghasilan maupun Pajak Pertambahan Nilai dari transaksi e-commerce ini. Berbagai kesulitan yang berkaitan dengan usaha mengidentifikasi identitas dan lokasi pihak-pihak yang bertransaksi, waktu dan lokasi penyerahan barang dan jasa pada transaksi e-commerce merupakan hal-hal yang memudahkan dan mendorong Wajib Pajak untuk berkelit memenuhi kewajiban perpajakannya. 
Karena kesulitan yang muncul ini banyak disebabkan dari penggunaan teknologi dalam transaksi, maka penyelesaian yang ada juga harus banyak memanfaatkan teknologi. Dalam hal ini pihak otoritas pajak harus mampu merespon dan mencari solusi guna memecahkan berbagai kesulitan yang ada, dan meminimalkan kemungkinan penghindaran pemenuhan kewajiban perpajakan oleh Wajib Pajak dengan menggunakan teknologi informasi dan komunikasi yang canggih pula. Berbagai solusi pemecahan kesulitan yang ada berbasis teknologi harus dituangkan dalam serangkaian mekanisme dan prosedur pengaturan yang wajib dilaksanakan oleh semua pihak yang akan melakukan transaksi e-commerce dalam suatu peraturan perpajakan khusus. Mengingat besarnya kemungkinan potensi penerimaan pajak yang bocor dari transaksi e-commerce, maka usaha-usaha yang serius untuk menyiapkan berbagai instrumen guna memaksimalkan potensi penerimaan pajak dari transaksi e-commerce harus menjadi prioritas.

Beberapa hal yang perlu untuk diatur secara khusus dalam peraturan perpajakan di Indonesia untuk mengefektifkan pemungutan Pajak Pertambahan Nilai antara lain:

1. Harus ditentukan definisi, batasan, kriteria transaksi e-commerce. Karena hal ini berhubungan dengan pemanfaatan teknologi informasi dalam transaksi bisnis yang mempunyai aspek luas dan tidak sekedar hanya pengaturan pajak untuk transaksi e-commerce, maka sebaiknya definisi, batasan dan kriteria ini diatur secara bersama oleh Kementerian Keuangan (Direktorat Jenderal Pajak), Kementerian Hukum dan HAM serta Kementerian
Komunikasi dan Informatika. Memang menurut Krensel (2004) tidak ada standar definisi transaksi e-commerce, karena definisi yang ada berbeda tergantung dari sumber dan penulis. Namun untuk kepastian penegakan hukum perlu ada suatu definisi yang jelas mengenai transaksi e-commerce. Di samping itu perlu pula ditentukan klasifikasi atau penggolongan transaksi e-commerce, khususnya untuk membedakan transaksi e-commerce penjualan produk digital dan bukan produk digital. Dalam hal ini bisa digunakan istilah direct $e$ commerce atau online untuk transaksi yang melibatkan produk digital dan indirect e-commerce atau offline untuk transaksi yang tidak melibatkan produk digital. Juga perlu ada pembedaan lebih lanjut berdasarkan pihak yang melakukan transaksi, khususnya yang melibatkan bisnis dan konsumen.

2. Harus dibuat daftar yang berisi rincian jenis transaksi e-commerce yang termasuk atau tidak termasuk objek Pajak Pertambahan Nilai.

3. Setiap pengelola situs yang menawarkan tempat/media bagi pihakpihak yang akan menjual barang dan jasa secara online (penyelenggara Online Marketplace, Classified Ads, Daily Deals dan penyelenggara layanan sejenisnya) harus mendaftarkan diri ke Kementerian Komunikasi dan Informatika, serta mendaftarkan diri ke Direktorat Jenderal Pajak sebagai Wajib Pajak dan Pengusaha Kena Pajak. Yang dimaksud pengelola situs di sini adalah pengelola situs yang hanya memberikan layanan tempat/media dan bukan sekaligus sebagai penjual barang dan atau jasa. 
4. Setiap pihak yang menjual barang dan atau jasa secara online melalui situs yang dikelolanya sendiri (penyelenggara Online Retail) harus pula mendaftarkan diri ke Kementerian Komunikasi dan Informatika serta mendaftarkan diri ke Direktorat Jenderal Pajak sebagai Wajib Pajak dan Pengusaha Kena Pajak.

5. Setiap pengelola situs yang menawarkan tempat/media bagi pihakpihak yang akan menjual barang dan jasa secara online harus mewajibkan semua pelanggannya yang berdomisili di Indonesia yang akan menjual barang dan jasa melalui tempat/media yang disediakannya untuk mempunyai Nomor Pokok Wajib Pajak dan Surat Pengukuhan sebagai Pengusaha Kena Pajak. Sedangkan apabila pelanggannya tidak bertempat kedudukan atau bertempat tinggal di Indonesia, maka pengelola situs tetap akan meminta data pelanggan tersebut yang berhubungan dengan kewajibannya sebagai Wajib Pajak Penghasilan dan Wajib Pajak Pertambahan Nilai (data semacam Nomor Pokok Wajib Pajak dan Pengukuhan sebagai Pengusaha Kena Pajak).

6. Setiap penyelenggara Online Marketplace, Classified Ads, Daily Deals, Online Retail dan penyelenggara layanan sejenisnya wajib melaporkan secara rutin setiap bulan semua transaksi penjualan barang dan jasa yang dilakukan melalui situs yang dikelolanya kepada Direktorat Jenderal Pajak. Laporan tersebut memuat secara lengkap data dari penjual dan pembeli termasuk identitas pembeli dan penjual, alamat lengkap dan asal negara penjual dan pembeli, alamat
IP (Internet Protocol Address) dari alat yang digunakan, lokasi transaksi, cara pembayaran, detil bank seperti lokasi bank dari rekening yang digunakan oleh kedua belah pihak untuk pembayaran, negara dari SIM card yang digunakan dan informasi penting lainnya.

7. Setiap pengelola situs seperti yang dimaksud pada angka 3. dan 5. akan memungut Pajak Pertambahan Nilai atas penyerahan jasa penyediaan tempat/media untuk penjualan barang dan jasa secara online.

8. Pihak yang akan menjual barang dan jasa melalui layanan online harus memungut Pajak Pertambahan Nilai, apabila barang dan jasa yang dijualnya tersebut termasuk Barang Kena Pajak (BKP) dan Jasa Kena Pajak (JKP).

9. Transaksi e-commerce yang dilakukan lintas negara, pemungutan Pajak Pertambahan Nilainya tetap menggunakan metode destination, artinya pengenaan Pajak Pertambahan Nilai dilakukan di negara di mana konsumsi dilakukan. Oleh karena itu untuk transaksi e-commerce yang tergolong transaksi ekspor akan dikenakan Pajak Pertambahan Nilai dengan tarif $0 \%$, serta yang termasuk transaksi impor akan dikenai Pajak Pertambahan Nilai dengan tarif $10 \%$.

10. Jika penjualan Barang Kena Pajak dan Jasa Kena Pajak melibatkan pihak penjual yang berkedudukan atau bertempat tinggal di luar negeri sedangkan pembeli bertempat kedudukan atau bertempat tinggal di dalam negeri, maka pemungutan Pajak Pertambahan Nilai dapat dilakukan dengan beberapa metode seperti: self assessment/reverse 
charge, registration of non residents, tax at source and transfer, collection by trusted third parties dan technology based solutions (Krensel, 2004). Dari beberapa metode ini, maka usulan yang disarankan adalah menggunakan metode self assessment/reverse charge bila pembelinya adalah pihak bisnis di dalam negeri yang umumnya sudah merupakan Wajib Pajak dan kemungkinan juga sudah merupakan Pengusaha Kena Pajak, serta menggunakan metode registration of non residents jika pembelinya di dalam negeri adalah pihak konsumen akhir. Penggunaan metode self assessment/reverse charge sudah diterapkan dalam Undang-Undang Pajak Pertambahan Nilai yang ada untuk pemungutan Pajak Pertambahan Nilai transaksi pemanfaatan Barang Kena Pajak tidak berwujud atau Jasa Kena Pajak dari luar daerah pabean di dalam daerah pabean.

11. Untuk pihak penjual dari luar negeri (non residents) yang harus melakukan registrasi sebagai Pengusaha Kena Pajak (PKP) berdasarkan metode registration of non residents harus dibuatkan mekanisme dan prosedur registrasi yang semudah dan sesederhana mungkin serta dilakukan secara online. Waktu penyelesaian registrasi diharapkan tidak lebih dari 72 jam. Demikian pula mekanisme dan prosedur pemenuhan kewajiban penyampaian Surat Pemberitahuan Masa untuk Pengusaha Kena Pajak luar negeri ini dibuat sesederhana mungkin dan disampaikan secara online pula.

12. Penyusunan peraturan yang dibuat harus melibatkan tenaga ahli yang menguasai dengan baik teknologi informasi dan komunikasi.

Semua hal tersebut di atas dapat diatur dalam Undang-Undang dan atau peraturan pelaksana lainnya yang dapat berupa Peraturan Pemerintah, Peraturan Menteri Keuangan, Peraturan Direktur Jenderal Pajak, Surat Edaran Direktur Jenderal Pajak atau peraturan pelaksana lainnya.

\section{KESIMPULAN}

Transaksi e-commerce dari tahun ke tahun terus meningkat, baik dari segi jumlah transaksi maupun besarnya nilai transaksi. Namun realisasi penerimaan pajak dari transaksi $e$ commerce ini masih sangat minim dan sangat jauh dari potensi penerimaan pajak yang seharusnya.

Hal ini disebabkan karena otoritas pajak kesulitan dalam melakukan pemungutan pajak atas transaksi $e$ commerce, termasuk pemungutan $\mathrm{Pa}$ jak Pertambahan Nilai. Kesulitan ini disebabkan oleh banyak faktor, antara lain karena kesulitan untuk mendeteksi terjadinya transaksi antara penjual dan pembeli, apalagi bila melibatkan produk digital yang lebih sulit lagi menelusurinya. Identifikasi mengenai data pihak-pihak yang bertransaksi juga biasanya sulit untuk didapat. Transaksi e-commerce yang melibatkan lintas negara (cross border) biasanya menimbulkan kesulitan tersendiri lagi.

Di Indonesia pengenaan pajak untuk transaksi e-commerce sudah diatur dalam Surat Edaran Direktur Jenderal Pajak Nomor SE-62/PJ/2013 tanggal 27 Desember 2013 tentang Penegasan Ketentuan Perpajakan atas transaksi e-commerce. Namun bila dibandingkan dengan apa yang sudah dilakukan oleh negara lain, apa yang diatur dalam Surat Direktur Jenderal 
Pajak ini masih belum cukup untuk mengatur pengenaan Pajak Pertambahan Nilai untuk transaksi $e$-commerce.

\section{SARAN}

Karena apa yang diatur dalam Surat Edaran Direktur Jenderal Pajak Nomor SE-62/PJ/2013 tanggal 27 Desember 2013 masih belum cukup untuk mengatur pengenaan pajak untuk transaksi e-commerce, maka perlu disusun serangkaian peraturan yang secara khusus mengatur pengenaan pajak, termasuk Pajak Pertambahan Nilai untuk transaksi e-commerce. Beberapa hal yang perlu diatur antara lain: definisi atau batasan transaksi e-commerce, klasifikasi atau penggolongan transaksi e-commerce, karakteristik barang dan jasa yang menjadi objek transaksi e-commerce, metode identifikasi atau pengumpulan data identitas dan lokasi pihak-pihak yang melakukan transaksi, pengaturan berkaitan dengan transaksi e-commerce lintas negara (cross border), mekanisme dan prosedur pemungutan, penyetoran, pelaporan, pengawasan dan penegakan hukum serta hal-hal penting lainnya.

Untuk menyusun peraturan yang khusus mengatur pengenaan pajak untuk transaksi e-commerce, beberapa rekomendasi dari OECD bisa digunakan sebagai acuan. Di samping itu aturan yang dibuat oleh negaranegara lain, seperti negara-negara Uni Eropa dapat pula digunakan sebagai referensi penyusunan aturan tersebut.

Dengan adanya suatu instrumen yang kuat berupa serangkaian peraturan dengan ruang lingkup yang luas, jelas, tegas dan rinci diharapkan potensi penerimaan pajak, khususnya Pajak Pertambahan Nilai dari transaksi e-commerce dapat dimaksimalkan. So- sialisasi dan koordinasi dengan berbagai instansi yang terkait, khususnya otoritas yang mengatur regulasi tentang informasi dan komunikasi menjadi salah satu kunci sukses dalam implementasi peraturan yang disusun.

\section{DAFTAR KEPUSTAKAAN}

Azam, Rifat, 2012, E-commerce Taxation in China, Paper was presented at the International Conference of Chinese Tax and Policy of the Journal of Chinese Tax Policy.

Basu, Subhajit, 2001, Taxation of Electronic Commerce, Liverpool.

Bellheim, Alexander, Caroline Brown, Fredrik Erneholm, Marcel Jundt, et al., 2014, Your Pocket Guide to VAT on Digital E-Commerce, Bird \& Bird Advokat KB, Stockholm, Sweden.

Borec, Tom, Michael Merz and Andras Salanki, 2013, World Wide VAT Forum: E-Commerce, Tax Planning International: Indirect Taxes BNA.

Bozdoğanoğlu, Burçin, 2015, ECommerce Taxation in National and International Area, International Journal of Humanities and Management Science (IJHMS), Vol. 3, Issue 3.

Hanefah, Hajah Mustafa Mohd, Haslinda Hassan and Zaleha Othman, 2008, E-Commerce Implications Potential Problems and Challenges in Malaysia, International Business Research, Vol. 1, No. 1, page 4357.

Hellerstein, Walter, 2002, Electronic Commerce and The Challenge for 
Tax Administration, Paper in Seminar on Revenue Implications of E-Commerce for Development, Geneva, Switzerland.

Kazemi, Amir and Soheil Sarmad Saeedy, 2015, Comparative Study of Effect of E-Commerce on Tax Structure in Selected Countries: Suggestions to Improve Tax System of Iran, International Journal of Information, Security and System Management, Vol. 4, No. 1, page 396-402.

Krensel, Andreas, 2004, VAT Taxation on E-Commerce, Dissertation, University of Cape Town.

Laudon, Kenneth C. and Carol Guercio Traver, 2004, E-commerce: Business, Technology, Society, Second Edition, Addison Wesley.

LCG International AG, 2013, Ecommerce Company in Luxembourg, Luxembourg.

Mahlunge, Amanda Nyasha, 2014, The New Dispensation Governing The Colletion of Value Added Tax on Electronic Commerce Supplies in South Africa, Dissertion, University of Cape Town.

Pandey, Dhirendra and Vishal Agarwal, 2014, E-commerce Transactions: An Empirical Study, International Journal of Advanced Research in Computer Science and Software Engineering, Vol. 4, Issue 3 , page 669-671.
Pronina, Tatiana, 2011, Indirect Taxation of Electronic Commerce: The U.S. and European Experience, Lessons for Russia, LL.M. Short Thesis, Central European University, Budapest, Hungaria.

Saxena, Gopal, 2015, Legal and Taxation Issues Concering ECommerce, The Indian Journal of Law and Technology, Vol. 11, page 87-105.

World Trade Organization, 2013, ECommerce in Developing Countries: Opportunities and Challenges for Small and Medium Sized Enterprises, World Trade Organization, Geneva, Switzerland.

Yapar, Burcu Kuzucu, Seda Bayrakdar, Mustafa Yapar, 2015, The Role of Taxation Problems on The Development of ECommerce, Procedia, ScienceDirect, Vol. 195, page 642-648.

Yu, Raymond, 2001, E-commerce: Relevance of Source and Residence Rules. 